\title{
Hypopituitarism in primary haemochromatosis; recovery after iron depletion
}

\author{
R Gama, MJ Smith, J Wright, V Marks
}

\begin{abstract}
Summary
We report a case of primary haemochromatosis complicated by anterior hypopituitarism which recovered after aggressive venesection therapy. Reversal of anterior hypopituitarism in haemochromatosis following iron depletion has not been previously described.
\end{abstract}

Keywords: haemochromatosis, hypogonadism, hypopituitarism

Hypogonadotrophic hypogonadism is a common complication of primary haemochromatosis in men and although other abnormalities of pituitary function are recognised, hypopituitarism is rare. ${ }^{1-6}$

We describe a man with primary haemochromatosis and anterior hypopituitarism. Pituitary function recovered following regular venesections. Reversal of hypopituitarism following iron depletion has not, to our knowledge, been previously reported.

\section{Case report}

In 1984 at the age of 42 years, the patient was diagnosed as having diabetes mellitus and haemochromatosis. The diagnosis of haemochromatosis was established on the basis of serum iron studies and a characteristic liver biopsy which showed no evidence of cirrhosis. $\mathrm{He}$ was started on subcutaneous insulin therapy, weekly venesections removing one pint of blood and advised to abstain from alcohol. Screening did not uncover other family members with haemochromatosis.

In 1986, he complained of lethargy, absent

Royal Surrey County Hospital, Guildford, Surrey, UK Department of Clinical Biochemistry and Nutrition R Gama J Wright V Marks Department of Medicine MJ Smith

Correspondence to Dr R Gama, Clinical Investigation Unit, Royal Surrey County Hospital, Guildford, Surrey GU2 5XX, UK libido, and impotence of two years duration. On examination he was hypogonadal. Endocrine investigations were consistent with hypopituitarism and, in particular, showed severe hypogonadotrophic hypogonadism (table). Computed tomography (CT) of the brain showed a normal hypothalamus and pituitary gland. He was prescribed intramuscular testosterone esters (Sustanon, Organon) building up to a maintenance dose of $500 \mathrm{mg}$ every month, $100 \mu \mathrm{g}$ oral thyroxine daily and $5 \mathrm{mg}$ oral prednisolone every morning. He rapidly felt well and his libido gradually returned.

Regular venesections continued until 1988, when he became anaemic (haemoglobin $8.8 \mathrm{~g}$ / dl) and iron deficient (serum iron $3.2 \mu \mathrm{mol} / 1$; reference range 10-30). Thereafter, he was venesected intermittently according to his serum iron concentrations. In 1989, he was prescribed oral mesterolone (Pro-viron, Schering Health) $50 \mathrm{mg}$ twice daily instead of Sustanon but otherwise continued on his other replacement therapy.

In 1994, he was referred to the department of medicine in Guildford, and anterior pituitary function was re-evaluated. Following withdrawal of prednisolone for 24 hours, serum cortisol increased from $467 \mathrm{nmol} / 1$ to $635 \mathrm{nmol} / \mathrm{l}$ one hour after intravenous administration of $250 \mu \mathrm{g}$ Tetracosactrin (Synacthen, CIBA Laboratories) suggesting recovery of the hypothalamic-pituitary-adrenal axis. Pituitary replacement therapy was withdrawn and three months later anterior pituitary function was normal (table). He remains well on insulin and in particular continues to enjoy normal sexual function.

\section{Discussion}

In haemochromatosis, excess iron is deposited in the pituitary gland and has a particular predilection for the gonadotrophs. ${ }^{7,8}$ Therefore, although hypogonadotrophic hypogonadism is common, symptomatic hypopituitarism is rare. ${ }^{1-6}$

Although considered irreversible, 9 three cases of partial and complete recovery from hypogonadotrophic hypogonadism following regular venesections have been reported. ${ }^{10-12}$ Our case is all the more remarkable, since the patient we described had extensive anterior pituitary disease in addition to marked hypogonadotrophic hypogonadism, all of which resolved following aggressive venesection therapy.

In conclusion, anterior hypopituitarism is a 
Table Results of investigations

\begin{tabular}{|c|c|c|c|}
\hline Investigation & 1986 & 1994 & Reference range \\
\hline Testosterone (nmol/l) & 0.7 & 18 & $10-30$ \\
\hline Luteinising hormone (IU/l) & 1.8 & 4 & $2-11$ \\
\hline Follicle-stimulating hormone (IU/l) & 1.0 & 4 & $1-9$ \\
\hline Total thyroxine (nmol/l) & - & 66 & $60-150$ \\
\hline Free thyroxine $(\mathrm{pmol} / \mathrm{l})$ & 5.0 & 12.4 & $9-24$ \\
\hline \multirow[t]{2}{*}{ Thyroid-stimulating hormone (mU/l) } & 2.1 & & $<5$ \\
\hline & & 1.52 & $1.5-3.5$ \\
\hline \multirow[t]{2}{*}{ Prolactin $(\mathrm{mU} / \mathrm{l})$} & 99 & & $<360$ \\
\hline & & 206 & $<600$ \\
\hline $\begin{array}{l}\text { Dehydroepiandrosterone sulphate } \\
(\mu \mathrm{mol} / \mathrm{l})\end{array}$ & $<0.1$ & 1.9 & $0.7-11.5$ \\
\hline $\begin{array}{l}\text { Peak cortisol response to insulin- } \\
\text { induced hypoglycaemia (nmol/1) }\end{array}$ & 346 & 570 & $>550$ \\
\hline $\begin{array}{l}\text { Peak growth hormone response to } \\
\text { insulin-induced hypoglycaemia (IU/l) }\end{array}$ & 16.2 & 49.3 & $>20$ \\
\hline Iron $(\mu \mathrm{mol} / \mathrm{l})$ & 51 & 27 & $10-30$ \\
\hline Iron-binding capacity $(\mu \mathrm{mol} / \mathrm{l})$ & 54 & 51 & $45-70$ \\
\hline$\%$ saturation & 94 & 53 & $20-55$ \\
\hline \multirow[t]{2}{*}{ Ferritin $(\mu \mathrm{g} / \mathbf{l})$} & 500 & & $36-262$ \\
\hline & & 33 & $15-330$ \\
\hline Total bilirubin $(\mu \mathrm{mol} / \mathrm{l})$ & 29 & 26 & $<20$ \\
\hline Aspartate aminotransferase (IU/l) & 48 & 26 & $<45$ \\
\hline Gamma glutamyl transferase (IU/l) & 26 & 24 & $<55$ \\
\hline \multirow[t]{2}{*}{ Alkaline phosphatase (IU/1) } & 121 & & $30-115$ \\
\hline & & 134 & $80-300$ \\
\hline Albumin $(g / 1)$ & 46 & 39 & $34-50$ \\
\hline Electrocardiogram & normal & & \\
\hline Chest X-ray & normal & & \\
\hline
\end{tabular}

1 McNeil LW, McKee LC, Lorber D, Rabin D. The endocrine manifestations of hemochromatosis. $\mathrm{Am} \mathcal{f} \mathrm{Med} S \mathrm{Ci}$ 1983; 285: 7-13.

2 Stocks AE, Martin FIR. Pituitary function in haemochromatosis. Am ₹ Med 1968; 45: 839-45.

3 Stocks AE. Powell LW. Pituitary function in idiopathic haemochromatosis and cirrhosis of the liver. Lancet 1972; 298-300.

4 Franchimont MSP, Murie N, Ferrand B, Van Cauwenberge $H$, Bourel M. Study of somatotrophic and gonadotrophic pituitary function in idiopathic haemochromatosis (31 pituitary function in idiopathic haemoch

5 Charbonnel B, Chupin M, Le Grand A, Guillon J. Pituitary function in idiopathic haemochromatosis: hormonal study in 36 male patients. Acta Endocrinol 1981; 98: 178-83.

6 Walsh CH, Wright AD, Williams JW, Holder G. A study of pituitary function in patients with idiopathic hemoch romatosis. F Clin Endocrinol Metab 1976; 43: 866-72.

7 MacDonald RA, Mallory GK. Hemochromatosis and hemosiderosis. Study of 211 autopsied cases. Arch Intern Med 1960; 105: 686-700.
Frequency of clinical features

at diagnosis in 145 men and

18 women with primary

haemochromatosis

Symptoms:

weakness and lethargy $83 \%$

abdominal pain $58 \%$

arthralgia $43 \%$

loss of libido or potency $38 \%$

amenorrhoea $22 \%$

dyspnoea on exertion $15 \%$

neurological symptoms $6 \%$

Physical findings:

hepatomegaly $83 \%$

pigmentation $75 \%$

loss of body hair $20 \%$

splenomegaly $13 \%$

peripheral oedema $12 \%$

jaundice $10 \%$

gynaecomastica $8 \%$

ascites $6 \%$

Other findings:

electrocardiogram changes $36 \%$

cirrhosis $69 \%$

oesophageal varices $9 \%$

Laboratory findings:

increase in serum transaminase activity $62 \%$ abnormal serum albumin concentration or

prothrombin time $18 \%$

diabetes mellitus $55 \%$

Abstracted from information appearing in $\mathrm{N} \mathrm{Englf}$

$\mathrm{Med}^{13}$ with permission

8 Peillon F, Racadot J. Modifications histopathologues de l'hypophyse dans 6 cas d'hemochromatose. Ann Endocrinol (Paris) 1969; 30: 800-7.

9 Bomford A, Williams R. Long-term results of venesection therapy in idiopathic haemochromatosis. Qf Med 1976; 45: 611-23.

10 Cundy T, Butler J, Bomford A, Williams R. Reversibility of hypogonadotrophic hypogonadism associated with genetic haemochromatosis. Clin Endocrinol 1993; 38: 617-20.

11 Kelly TM, Edwards CQ, Meikle AW, Kushner JP. Hypogonadism in haemochromatosis: reversal with iron depletion. Ann Intern Med 1984; 101: 629-632.

12 Siemons LJ, Mahler C. Hypogonadotrophic hypogonadism in hemochromatosis: recovery of reproductive function after in hemochromatosis: recovery of reproductive function after

13 Niederau C, Fischer R, Sonnenberg A, Stremmel W,

Trampisch HJ, Strohmeyer G. Survival and causes of death Trampisch HJ, Strohmeyer G. Survival and causes of death
in cirrhotic and in noncirrhotic patients with primary in cirrhotic and in noncirrhotic patients with prim
hemochromatosis. $N$ Engl $f$ Med 1985; 313: 1256-62. 